\title{
Blended-Learning: The Responses from Non-English Students in the Indonesian Tertiary Context
}

\author{
Fatimah Mulya Sari ${ }^{1}$, Achmad Yudi Wahyudin ${ }^{2}$ \\ fatimah@teknokrat.ac.id ${ }^{1}$, achmad.yudi@teknokrat.ac.id ${ }^{2}$ \\ Universitas Teknokrat Indonesia
}

\begin{abstract}
The process of language teaching and learning has undergone major changes due to the developments of technology. The use of technology in education field has paved the way for higher education institution to innovatively shape their modern media in a language teaching and learning. Subsequently, the implementation of blended-learning has aroused at the Universitas Teknokrat Indonesia for approximately one and a half year ago to maximize the use of technology. Most lecturers in all study programs have increasingly utilized the social network sites such as Instagram, Facebook, WhatsApp, etc. for the successfulness of blended-learning. This present study aims at exploring the students' responses on how blended-learning might be used to develop their language learning and discovering their attitudes towards the implementation of blended-learning as an interactional teaching and learning tool in English for Business course. Employing a qualitative in form of a case study, eighty-two undergraduate students from study program of Informatics Engineering were observed, interviewed, and distributed questionnaires. The data were performed to collect the students' responses and students' attitudes toward the implementation of blendedlearning in the process of their language learning. The findings were found out that most students from Informatics Engineering major showed their positive responses and positive attitudes using blended learning for the language teaching and learning. They also gained some educational benefits for their English language development. Thus, this blended learning brings us to the new trend for language teaching and learning media in order to motivate the students in enhancing their language acquisition.
\end{abstract}

Keywords: blended-learning, language teaching, students' attitudes, social network sites

\section{Introduction}

Foreign language learners, especially in Indonesia, have experienced the significant of teaching and learning process inside the classroom due to the development of technology in the education field. Nowadays, most of foreign language learners learn and acquire the target language primarily through online learning or blended learning. Subsequently, most of English language teachers have started to understand and explore how these blendedlearning can be integrated in their formal language classes (Thorne \& Black, 2007; Kern, Ware, \& Warschauer, 2008; Harrison \& Thomas, 2009; Kessler, 2013; \& Prichard, 2013). Moreover, blended learning environment allows English language teachers to adapt their roles along a continuum from a facilitator to the traditional formal instructor. Thus, L2 teachers have to be clearly defined and comprehended their roles in the teaching and learning activities to support a fruitful learning environment using blended learning.

The implementation of blended learning using social network sites (SNS) has predominantly provided a co-operative, formal, and informal education settings. Justification for relevant studies has derived from the common view and perception that the social network sites could be effectively employed in the L2 education. Current studies have explored the use and impacts of social network sites such as Facebook, Instagram, Blog, 
Youtube, and others for augmenting learners' language acquisition in the process teaching and learning, with the majority focused upon the higher education sector. The key features of these social network sites appear to encourage students to develop several English skills such as writing, reading, speaking, and listening (Prichard, 2013). They also serve language learners with the ability to engage in meaningful social and cultural exchanges with other learners. In addition, language learners in this technology era are afforded with the skills to act more autonomously using social media (Barton and Potts, 2013). They engage as active participant. Undoubtedly, it has a potential for language learning enhancement for English for Foreign Language (EFL) learners. The previous study revealed that social network site of Instagram might be considered as an effective pedagogical tool as the result of study gained positive attitudes from the students and gained good impact and interest towards their language learning (Kelly, 2015; Mansor \& Rahim, 2015). Another point is that the use of social media resulted in more engaged students in their studies, improved attendance, and higher completion rates. Furthermore, there was evidence that the teachers input into social media possibly promoted more focused and specific discussions of course.

Based on the pre-observation at Universitas Teknokrat Indonesia, the English teachers and students were favorably supportive of the utility of social network site or social media for their process of teaching and learning. Both of teachers and students were impressed by the quality of the online materials being used in their online teaching material and the integration of the various forms of social media used to regularly engage and communicate in the classroom. The English teachers also had no major issues in accessing social media while in the teaching process. In addition, the English teacher emphasized the educational benefits from the use of social media in the teaching and learning system; such as, the students are more active to interact with the teacher and other classmates because they enjoy learning through social media. Therefore, considering the variance findings amid the current studies and literature, this study investigated learners' attitudes toward blended learning and how this platform might be used to develop their language learning acquisition.

\section{Method}

To explore the purposes of this study, a case study was adopted within the qualitative research paradigm. The subjects of this research were 82 non-English students, majoring Informatics Engineering, Faculty of Engineering and Computer Science, Universitas Teknokrat Indonesia. They took the general course of English for Business in the first semester in the academic year of 2017/2018. The language learning activities given to the students were that they were given the materials to be discussed and at last they created some video projects based on the topics given such as business telephoning, customer service, and advertisement. They were asked to do and accomplish their projects in pair. The lecturer only involved as an observer, facilitator, and instructor.

The data collection employed were non-participant observation, open-ended interview, and questionnaire. The questionnaires were distributed to all respondents consisting of 15 statements. To analyze the questionnaires, the writers decided to interpret the range of scores based on Riduwan (2008). This interpretations were used to find out the students' attitude toward the implementation of blended learning in their teaching and learning process. The scores interpretation are: (1) item percentage of 0 - 20\% shows very insignificant result; (2) item percentage of $21-40 \%$ shows insignificant result; (3) item percentage of $41-60 \%$ shows neutral or moderate result; (4) item percentage of $61-80 \%$ shows significant result; and (5) item percentage of $81-100 \%$ shows very significant result. Meanwhile, the interview was conducted to reveal the students' response toward the implementation of blended learning in their language learning activities. The interview questions were about their 
responses toward the implementation of blended-learning in their learning process. They were interviewed for 10-15 minutes. After that, the interview data were transcribed.

\section{Findings and Discussion}

This section discusses the findings of study. To explore the students' attitudes toward blended learning, the questionnaires consisting of fifteen questions were distributed to eighty-two students. The table 1 quantitatively describes the attitudes of the learners about blended learning as their learning method. The each statement from the questionnaire were measured based on the scale of 1 to 5 with different indicators; scale 5 referring to strongly agree or very significant result, scale 4 referring to agree or significant result, scale 3 referring to neutral or moderate result, scale 2 referring to disagree or insignificant result, and scale 1 referring to strongly disagree or very insignificant result. The detail results can be seen in the following table, as follows:

Table 1. Students' Attitudes toward Blended Learning

\begin{tabular}{|c|c|c|c|c|c|c|}
\hline No & Statements & 5 & 4 & 3 & 2 & 1 \\
\hline 1 & "Blended learning is interesting." & $\begin{array}{c}7 \\
(8,54 \%)\end{array}$ & $\begin{array}{c}48 \\
(58,54 \%)\end{array}$ & $\begin{array}{c}24 \\
(29,27 \%)\end{array}$ & $\begin{array}{c}3 \\
(3,66 \%)\end{array}$ & $\begin{array}{c}0 \\
(0 \%)\end{array}$ \\
\hline 2 & $\begin{array}{l}\text { "I really like learning activity using } \\
\text { this method." }\end{array}$ & $\begin{array}{c}7 \\
(8,54 \%)\end{array}$ & $\begin{array}{c}21 \\
(25,61 \%)\end{array}$ & $\begin{array}{c}42 \\
(51,22 \%)\end{array}$ & $\begin{array}{c}12 \\
(14,63 \%)\end{array}$ & $\begin{array}{c}0 \\
(0 \%)\end{array}$ \\
\hline 3 & $\begin{array}{l}\text { "This learning method helps me to } \\
\text { improve my English skills at } \\
\text { present and in the future." }\end{array}$ & $\begin{array}{c}11 \\
(13,41 \%)\end{array}$ & $\begin{array}{c}33 \\
(40,24 \%)\end{array}$ & $\begin{array}{c}28 \\
(34,15 \%)\end{array}$ & $\begin{array}{c}10 \\
(12,2 \%)\end{array}$ & $\begin{array}{c}0 \\
(0 \%)\end{array}$ \\
\hline 4 & $\begin{array}{l}\text { "This learning method helps me to } \\
\text { develop teamwork skills." }\end{array}$ & $\begin{array}{c}6 \\
(7,32 \%) \\
\end{array}$ & $\begin{array}{c}47 \\
(57,32 \%) \\
\end{array}$ & $\begin{array}{c}19 \\
(23,17 \%) \\
\end{array}$ & $\begin{array}{c}10 \\
(12,2 \%) \\
\end{array}$ & $\begin{array}{c}0 \\
(0 \%) \\
\end{array}$ \\
\hline 5 & $\begin{array}{l}\text { "This learning method provides an } \\
\text { opportunity to improve democrarcy } \\
\text { thinking skills by listening to my } \\
\text { colleagues' opinions and accepting } \\
\text { the different points." }\end{array}$ & $\begin{array}{c}11 \\
(13,41 \%)\end{array}$ & $\begin{array}{c}51 \\
(62,2 \%)\end{array}$ & $\begin{array}{c}15 \\
(18,29 \%)\end{array}$ & $\begin{array}{c}5 \\
(6,1 \%)\end{array}$ & $\begin{array}{c}0 \\
(0 \%)\end{array}$ \\
\hline 6 & $\begin{array}{l}\text { "This learning method helps to } \\
\text { improve my creative thinking } \\
\text { skills." }\end{array}$ & $\begin{array}{c}13 \\
(15,85 \%)\end{array}$ & $\begin{array}{c}46 \\
(56,1 \%)\end{array}$ & $\begin{array}{c}18 \\
(21,95 \%)\end{array}$ & $\begin{array}{c}5 \\
(6,1 \%)\end{array}$ & $\begin{array}{c}0 \\
(0 \%)\end{array}$ \\
\hline 7 & $\begin{array}{l}\text { "Learning English for Business } \\
\text { with the blended learning makes me } \\
\text { happy and fun." }\end{array}$ & $\begin{array}{c}7 \\
(8,54 \%)\end{array}$ & $\begin{array}{c}32 \\
(39,02 \%)\end{array}$ & $\begin{array}{c}29 \\
(35,37 \%)\end{array}$ & $\begin{array}{c}14 \\
(17,07 \%)\end{array}$ & $\begin{array}{c}0 \\
(0 \%)\end{array}$ \\
\hline 8 & $\begin{array}{l}\text { "This learning method makes me } \\
\text { feel bored and I do not want to } \\
\text { study with this method." }\end{array}$ & $\begin{array}{c}0 \\
(0 \%)\end{array}$ & $\begin{array}{c}15 \\
(18,29 \%)\end{array}$ & $\begin{array}{c}33 \\
(40,24 \%)\end{array}$ & $\begin{array}{c}31 \\
(37,8 \%)\end{array}$ & $\begin{array}{c}3 \\
(3,66 \%)\end{array}$ \\
\hline 9 & $\begin{array}{l}\text { "I do not like working group } \\
\text { because our group have different } \\
\text { ability and ideas." }\end{array}$ & $\begin{array}{c}0 \\
(0 \%)\end{array}$ & $\begin{array}{c}4 \\
(4,88 \%)\end{array}$ & $\begin{array}{c}32 \\
(39,02 \%)\end{array}$ & $\begin{array}{c}36 \\
(43,9 \%)\end{array}$ & $\begin{array}{c}10 \\
(12,2 \%)\end{array}$ \\
\hline 10 & $\begin{array}{l}\text { "There is no English skills } \\
\text { improvement after using this } \\
\text { activity." }\end{array}$ & $\begin{array}{c}0 \\
(0 \%)\end{array}$ & $\begin{array}{c}5 \\
(6,15)\end{array}$ & $\begin{array}{c}21 \\
(25,61 \%)\end{array}$ & $\begin{array}{c}46 \\
(56,1 \%)\end{array}$ & $\begin{array}{c}10 \\
(12,2 \%)\end{array}$ \\
\hline 11 & $\begin{array}{l}\text { "If I have a chance to study English } \\
\text { course deeper, I really want to have } \\
\text { a blended learning." }\end{array}$ & $\begin{array}{c}6 \\
(7,32 \%)\end{array}$ & $\begin{array}{c}29 \\
(35,37 \%)\end{array}$ & $\begin{array}{c}31 \\
(37,8 \%)\end{array}$ & $\begin{array}{c}16 \\
(19,51 \%)\end{array}$ & $\begin{array}{c}0 \\
(0 \%)\end{array}$ \\
\hline 12 & $\begin{array}{l}\text { "This learning method is time- } \\
\text { wasting and time-consuming." }\end{array}$ & $\begin{array}{c}4 \\
(4,88 \%) \\
\end{array}$ & $\begin{array}{c}12 \\
(14,63 \%)\end{array}$ & $\begin{array}{c}44 \\
(53,66 \%)\end{array}$ & $\begin{array}{c}22 \\
(26,83 \%)\end{array}$ & $\begin{array}{c}0 \\
(0 \%)\end{array}$ \\
\hline 13 & $\begin{array}{l}\text { "This learning method helps to } \\
\text { create opportunity for } \\
\text { communication. Whenever I make } \\
\text { mistakes, I will revise them to be a } \\
\text { perfect assignment/practice." }\end{array}$ & $\begin{array}{c}4 \\
(4,88 \%)\end{array}$ & $\begin{array}{c}48 \\
(58,54 \%)\end{array}$ & $\begin{array}{c}19 \\
(23,17 \%)\end{array}$ & $\begin{array}{c}11 \\
(13,41 \%)\end{array}$ & $\begin{array}{c}0 \\
(0 \%)\end{array}$ \\
\hline
\end{tabular}




\begin{tabular}{c|l|c|c|c|c|c}
\hline 14 & $\begin{array}{l}\text { "This learning method makes me } \\
\text { feel confident and relaxing." }\end{array}$ & $\begin{array}{c}11 \\
(13,41 \%)\end{array}$ & $\begin{array}{c}38 \\
(46,34 \%)\end{array}$ & $\begin{array}{c}33 \\
(40,24 \%)\end{array}$ & $\begin{array}{c}0 \\
(0 \%)\end{array}$ & $\begin{array}{c}0 \\
(0 \%)\end{array}$ \\
\hline \multirow{2}{*}{15} & $\begin{array}{l}\text { "This learning method makes me } \\
\text { stress and not exciting. I am } \\
\text { somewhat shy when I am being part } \\
\text { of the activity." }\end{array}$ & $\begin{array}{c}8 \\
(9,76 \%)\end{array}$ & $\begin{array}{c}17 \\
(20,73 \%)\end{array}$ & $\begin{array}{c}17 \\
(20,73 \%)\end{array}$ & $\begin{array}{c}38 \\
(46,34 \%)\end{array}$ & $\begin{array}{c}2 \\
(2,44 \%)\end{array}$ \\
\hline
\end{tabular}

Based on the results of the questionnaire, there were various responses from the students. Each statement has different percentage. For the first statement, there were 48 students $(58,54 \%)$ who agreed that blended learning is interesting. Besides, there were 24 students $(29,27 \%)$ who were neutral or moderate. Seven students $(8,54 \%)$ strongly agreed that it is interesting. Three students $(3,66 \%)$ disagreed toward these statement. On the other hand, the highest percentage for the second statement was $51,22 \%$. There were 42 students who were in neutral or moderate thinking that they really liked learning activity using blended learning. Beside that, twenty-one students $(25,61 \%)$ showed significant result and seven students $(8,54 \%)$ strongly agreed that they liked learning English using blended learning. The rest of students $(14,63 \%)$ had insignificant result in which they disagreed toward this statement. This results were strengthened by the students' responses in the interview. It could be seen in the following extracts:

Ma : "I really like blended learning because it is interesting. We can learn any where and can browse another materials relevant with our course from Google."

Ji : "Yup, I love it. It make me easy to study outside the class and I can study together with my friends in the comfortable place like cafe."

Ch : "Really interesting because I can study using another media like mobile phone or laptop to access this kind of learning."

Od : "Blended learning makes us easy to do assignment or video projects. We only upload it and give comments to each posting from other friends. It's fun."

Ag : "It is interesting and also simple to join the meeting because we only need to provide an internet quotas."

Ko : "Of course I really like it. Because it makes the students more independent in doing project and assignment and more creative."

In third statement, more than $50 \%$ students showed significant result that blended learning helped them to improve their English skills at present and in the future. Only ten students $(12,2 \%)$ who disagreed about its statement. On the other hand, there were twenty eight students in the percentage of $34,15 \%$ who were in neutral section. In reverse, most students insignificantly or disagreed that there was no English skills improvement after using blended learning in their learning and teaching process $(56,1 \%)$. Ten students $(12,2 \%)$ also strongly disagreed with its statement. Then, there were only twenty-one students $(25,61 \%)$ who chose neutral. This results were also clearly reflected from the students' interview, as follows:

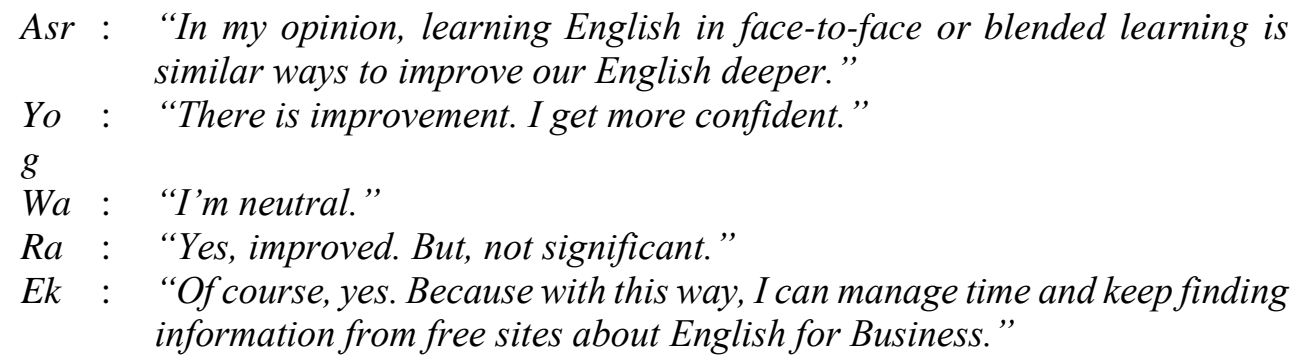



$A b$ : "Blended learning help me to increase my scores and speaking by doing project for telephoning and others video."
Ve : "The improvement is enough but not too much."
Gi : "This blended learning brings positive result because it motivates me to do or act in public."

Most students agreed that blended learning helped them to develop teamwork skills and provided an opportunity to improve democracy thinking ability toward their colleagues' opinions resulting on accpeting the different points. The percentage reached above $55 \%$. Unfortunately, there were 34 students $(41,46 \%)$ showed moderate result and seventeen students $(18,3 \%)$ showed insignificant result or disagreed on these statement. In addition, the learning activities given to the students during blended learning was that they accomplished some projects in pair such as practicing business telephoning and customer service. There were $56,1 \%$ (46 students), referring to significant result or agree, and $15,85 \%$ (13 students), referring to very significant result, who gave positive choices that blended learning helped them to improve their creative thinking skills since they had to arrange their own conversation and setting for the video-take.

On the other hand, most students believed that learning English using blended learning helped them to create opportunity for communication. When they made mistakes in taking video, they could revise it to be perfect assignment or project. There were forty-eight students $(58,54 \%)$ showing the significant result and four students $(4,88 \%)$ showing very significant result toward this statement. Besides, nineteen students $(23,17 \%)$ became neutral or moderate in this section and eleven students $(13,41 \%)$ disagreed with it.

Most students said that learning English fo Business using blended learning made them feel happy and fun. There were thirty-nine students $(47,56 \%)$ who felt the positive results. The other twenty-nine students $(35,27 \%)$ were in neutral group. Unfortunately, fourteen students $(17,07 \%)$ disagreed about it. Moreover, a half of total from the respondents felt neutral $(53,66 \%)$ if blended learning was time-wasting and time-consuming. The other 22 students $(26,83 \%)$ also disagreed about this statement. Besides that, there were thirty-eight students $(46,34 \%)$ who showed insignificant results about their opinion that blended learning made them stress and shy when they were being part of the project or classroom activities.

Furthermore, the results of questionnaires showed different interpretation in each statement. The interpretations revealed that the students gave positive responses and attitudes to the implementation of blended learning in their language teaching and learning process. The results give positive insight to implement this blended learning in the language learning process as the educational benefits are achieved by the students. The majority of observed students agreed that their use of blended learning using social media had encouraged them to be more engaged and interested in their language learning. Most students revealed that their language learning becomes more interesting, fun, confident, and relaxing. Also, they were stated that they were also learning more from other students. In addition, it is clearly seen that blended learning is a rich learning environment in which learner-centered approach results the significant opportunities for language learning and also provides new ways of language teaching and learning.

\section{Conclusion}

In the light of the results, it can be concluded that most students showed their positive responses and attitudes toward the implementation of blended learning in their language teaching and learning process. There is no doubt that blended learning is as a new and effective learning method for the students' interactions and communication, especially in the discussion of their projects. Most students revealed that blended learning is interesting, fun, 
and more relaxing. They also admitted that there were improvements for their creative thinking, teamwork skill, and democracy thinking. Through this successful way of teaching, the students are fueled their interest towards language learning. Both teachers and learners have a significant role on the effectiveness of using blended learning in the teaching and learning activities. Language teachers in online learning is an important key when integrating blended learning into foreign language classroom. Therefore, this study is desired to serve educational insight for the future research. It is hoped that further research will be more focus on blended learning using some essentials tools of social network sites.

\section{Acknowlegdement}

The writers would like to express their sincere gratitude to the Ministry of Research, Technology, and Higher Education for granting this research (No: 0045/E3/LL/2018, 16 January 2018).

\section{References}

Barton, D. \& Potts, D. 2013. Language Learning Online as a Social Practice. TESOL Quarterly. 47/4. 815-820.

Kelly, Ronan. 2015. An Exploration of Instagram to Develop ESL Learners' Writing Proficiency. Ulster University: A Dissertation.

Harrison, R., Thomas, M. 2009. Identity in Online Communities: Social Networking Sites and Language Learning. International Journal of Emerging Technologies \& Society. 7/2. 109-124.

Kern, R., Ware, P., Warschauer, M. 2008. Network-Based Language Teaching. Encyclopedia of Language and Education. 2/4. 281-292.

Kessler, G. 2013. Teaching ESL/EFL in a World of Social Media, Mash-Ups, and HpyerCollaboration. TESOL Journal. 4/4. 615-632.

Mansor, N. \& Rahim, N. A. 2017. Instagram in ESL Classroom. Man in India, 97(20), pp. 107-114.

Prichard, C. 2013. Training L2 Learners to Use Facebook Appropriately and Effectively. CALICO Journal. 30/2. 204-225.

Prichard, C. 2013. Using Social Networking Sites as a Platform for Second Language Instruction. TESOL Journal. 4/4. 752-758.

Riduwan. 2008. Belajar Mudah Penelitian untuk Guru-Karyawan dan Peneliti Pemula. Bandung: Alfabeta.

Thorne, S. L., Black, R. W. 2007. Language and Literacy Development in Computermediated Contexts and Communities. Annual Review of Applied Linguistics. 27. 133-160. 